\title{
Література:
}

1. Dancygier B., Sweetser E. Mental Spaces in Grammar. Conditional Constructions. Cambridge: Cambridge University Press, 2005. 295 p.

2. Fauconnier G. Mappings in Thought and Language. Cambridge. Cambridge University Press, 1997. 240 p.

3. Fauconnier G. Mental Spaces: Aspects of Meaning Construction in Natural Language. Cambridge. Cambridge University Press, 1994. 240 p.

4. Lakoff G., Johnson M. Metaphors We Live By. Chicago: University of Chicago Press, 1980.

5. Langacker R. Foundations of Cognitive Grammar: Volume I: Theoretical Prerequisites. Stanford California, CA: Stanford University Press, $1987.516 \mathrm{p}$.

6. Sinha C. Cognitive Linguistics, Psychology and Cognitive Science // The Oxford Handbook of Cognitive Linguistics [Ed. by D. Geeraerts and H. Cuycken]. Oxford. Oxford University Press, 2010. P. 1266-1294.

7. Sweetser E. From Etymology to Pragmatics: Metaphorical and Cultural Aspects of Semantic Structure. Cambridge: Cambridge University Press, 1990. $174 \mathrm{p}$.

8. Talmy L. Toward a Cognitive Semantic. Typology and Process in Concept Structuring. Cambridge: MIT Press, 2000. 504 p.

DOI https://doi.org/10.30525/978-9934-26-110-7-37

\section{ЛЕКСИЧНІ ЗАСОБИ ФРАЗЕОЛОГІЗАЦІЇ СТЕРЕОТИПІВ}

\author{
Орел I. I. \\ кандидат філологічних наук, дочент, \\ дочент кафедри романо-германської філології \\ Рівненський державний гуманітарний університет \\ м. Рівне, Украӥна
}

Питання лінгвістичної репрезентації стереотипів привертає увагу багатьох мовознавців, які присвячують свої дослідження зазначеній проблемі. У працях Алефіренка М., Вежбицької А., Кононенко В., Кубрякової О., Радзієвської Т., Степанова Ю. схарактеризовано особливості шляхів вербальної репрезентації результатів мислення представників певного етносу, що відображають стереотипи. Маслова В. описує проблеми мовної об'єктивації стереотипних уявлень з урахуванням особливостей національної картини світу. Срмоленко С., Космеда Т. 
висвітлюють проблему мовного вираження стереотипів у художніх текстах. Сгорова О. І., Коротун А. Г. аналізують особливості лінгвалізації гендерних стереотипів фемінності в англомовному рекламному дискурсі. У дисертаційному дослідженні Велінбахової О. Л. описано моделі репрезентації стереотипів на матеріалі російської мови. Дослідниця виокремлює номінативні та синтаксичні способи омовлення стереотипів, розглядає засоби їх реалізації [1, с. 12-13].

Проте, не дивлячись на низку існуючих розвідок, присвячених вивченню проблем вербалізації стереотипів, указане питання лишається не достатньо дослідженим, оскільки повністю не з'ясовані засоби вербалізації мовних стереотипів, способи передачі національно-специфічних рис стереотипної оцінки при їх мовній об'єктивації, не встановлено шляхи взаємодії категоризованих ознак стереотипізованого образу чи ситуації із семантичними компонентами мовного знаку, обраного для номінації стереотипу. Вивчення способів лінгвалізації стереотипів, зокрема засобами фразеологічних одиниць (далі - ФО) на матеріалі німецької мови, потребує подальших розвідок, тому що дослідження щодо способів та засобів мовного вираження стереотипних уявлень засобами ФО не проводилися. Це зумовлює актуальність нашого дослідження. Метою пропонованої розвідки є виявлення лексичних засобів фразеологічної номінації німецьких стереотипів і аналіз їх впливу на формування цілісного фразеологічного значення (далі - ФЗ).

Відомо (Алефіренко М. Ф., Баран Я. А., Виноградов В. В., Гаврись В. І., Кунін О. В., Потебня О. О., Пророченко О. П., Райхштейн О. Д., Селіванова О. О., Степанова М. Д., Телія В. М., Чернишова I. I., Фляйшер В.), що основа фразеологічного семіозису - це перенесення значення слова/ словосполучення/ речення. Переосмислення відбувається на основі виокремленої ознаки образу внутрішньої форми, який розглядається крізь призму національної культури, що й забезпечує національно-специфічне бачення об'єктивної реальності. Виокремлена ознака категоризується, що уможливлює репрезентацію стереотипного уявлення засобами обраного мовного знака. ФО має образну основу, яка містить набір ознак, що активуються через семи ФЗ. У процесі реалізації семантики ФО семи актуалізуються з різною інтенсивністю, створюючи відтінки значення, які відображає конотативний компонент. Ми вважаємо, що це пов'язано із обраною для категоризації ознакою образу i iii місця на ціннісній шкалі національної культури. Ядерна сема ніби підсвічується периферійними семами, що формує цілісне розуміння ФЗ.

Зауважимо, що переосмислюються образні вирази, внутрішня форма яких містить певний набір ознак. Окреме переосмислення таких ознак 
сприяє утворенню різних ФО для вербалізації різноманітних понять. Наприклад, образ зайця використано у низці ФО, які вербалізують стереотипне уявлення про молодість і недосвідченість (heuriger/ junger Hase sein - бути недосвідченим - ФО виникло на основі спостереження за молодими зайцями, яких легко зловити), або, навпаки, про значний досвід (alter Hase sein - бути стріляним горобцем - старого зайця вполювати важко, через його манеру втікати), про страх (Angsthase sein бути боягузом - ФО виникла на основі спостереження за куцим заячим хвостом, який починав тремтіти перед початком втечі), про обізнаність у справі (wissen, wie der Hase läuft - знати, як щось працює/ відбувається втікаючи, заєць петляє, підстрибує, щоб дезорієнтувати нападника), про значну відстань (wo sich Fuchs und Hase Gute Nacht sagen - десь дуже далеко - ФО виникла на основі казок) [5], про смачну страву (falscher Hase - запечений рулет із м'ясного фаршу із вареним яйцем усередині рецепт і назва страви походять із складних повоєнних часів після Другої світової війни, коли люди часто намагалися виживати з полювання (зайчатина була улюбленою стравою). Унаслідок великого попиту популяція зайців значно зменшилась і потрапила під захист. М'ясо лишалося дефіцитним продуктом, а фарш (продукт не найкращої якості) доступним [4]).

Проведений нами аналіз фактичного матеріалу встановив, що номінація стереотипів засобами ФО відбувається: на основі образу, що транслюється смислоутворюючою лексемою у структурі ФО, або на основі пресупозиції. У межах пропонованої розвідки зосередимо увагу на виявленні номінативних засобів формування семантики на підставі стержневої лексеми у структурі ФО.

Смислоутворююча лексема пов'язана із національно-культурним баченням стереотипізованого образу та його оцінки. Стереотипізований образ є основою внутрішньої форми ФО. У ході номінації стереотипного уявлення активується лише обрана ознака образу, що забезпечує відповідний вибір мовного знака для ії репрезентації. Обраний мовний знак актуалізує саме ту сему, яка репрезентує виокремлену ознаку образу внутрішньої форми.

Семантика ФО має яскравий конотативний компонент, що визнано домінантним у структурі ФЗ (функція ФО полягає у характеристиці денотата). Тому, для адекватного і повного розуміння цілісного Ф3 необхідно враховувати фонові знання, які виступають тлом формування семантики ФО (особливо компонентів конотату) на основі ознаки/ ознак образу внутрішньої форми, репрезентованої стержневою лексемою. Семемний склад актуалізованої/ ядерної семи смислоутворюючої 
лексеми розкривається за умов ономасіологічного аналізу із урахуванням фонових знань.

Нами виявлено стержневі лексичні компоненти ФО, які пов'язують Ф3 із стереотипізованим образом: антропоніми, етноніми, оніми (прономени (ім'я), номен (прізвище), когномени (прізвиська) [2]), зооніми, фітоніми, топоніми, гідроніми, нумеративи, колороніми, артефакти, фольклоризми, гасроніми, грошові одиниці, частини тіла (людини/ тварини), одяг/ головні убори/ взуття (їх частин), музичні інструменти, одиниці міри ваги/ довжини.

Процес фразеологізації стереотипного уявлення грунтується на перенесенні/ переоцінці значення одної семи, яка відображає ту ознаку, що є основою категоризації. Механізмами такого переосмислення є метафоризація, метонімізація, метафтонімізація, лексичний зсув, звуження чи розширення значення, погіршення/ покращення значення [3]. Наприклад, ФО із компонентом Hans репрезентують низку автостереотипів. Як свідчать фразеографічні джерела, перші ФО із указаним компонентом зафіксовані у XIV ст. Чоловіче ім'я Hans - скорочений варіант від Johannes - було поширеним у Середні віки. Завдяки проповідям лютеранського священика Грегоріуса Штрігенітіуса виникло вірування у те, що дім, у якому живе Ганс, ніколи не матиме жодних негараздів [5]. Тобто, ім'я виконувало функцію оберегу, через що отримало позитивну оцінку. Це сприяло використанню імені для номінації стереотипів: «активна, багатостороння, затребувана людина» - Hansdampf in allen Gassen (метафоризація); «щасливчик» - Hans im Glück (метафтонімія); «поважна/ багата особа» - ein großer Hans/ Großhans (метафтонімія) [5]. У ході суспільно-історичних змін у кінці XV ст. поширилися ФО ein dummer Hans - дурень, ein kleiner Hans/ Kleinhans - «маленька» людина/ не важлива особа. Iз XVI ст. ФО ein großer Hans та ein kleiner Hans означали фізичні характеристики чоловіків. Ім'я Hans у результаті семантичного звуження отримало значення $\mathrm{Kerl}$, що сприяло формуванню ФО для вербалізації негативних уявлень про інтелектуальні характеристики інгрупи: Prahlhans - (розм.) хвалько; Hanswurst - (розм., грубо) дурень, телепень; armer Hans - (розм.) бідолаха; Hans Mist (грубо, зневажл.) селюк; Hans Ohnesorge - безтурботний, бездумний [5].

Отже, фразеологічна номінація стереотипних уявлень відбувається лексичними засобами, які виконують функцію смислоутворюючого компонента у будові ФО. Ця лексема пов'язує стереотипізовану ознаку образу внутрішньої форми із семантичною структурою ФЗ, активуючи не лише ідентифікуючу сему, але й потенційні семи, які сприяють формуванню конотату. Створення і зміна ФЗ відбувається у результаті 
переоцінки ознаки образу внутрішньої форми. Розуміння цілісного Ф3 можливе у ході ономасіологічного аналізу, який проводиться із урахуванням фонових знань.

Перспективами подальших досліджень вбачаємо аналіз номінації стереотипів засобами ФО, що утворилися на основі пресупозицій.

\title{
Література:
}

1. Вилинбахова Е. Л. Модели репрезентации стереотипов в русском языке: автореф. дис. ... канд. філол. наук. С.-Петербург: 10.02.19. 2011. $22 \mathrm{c}$.

2. Система імен в Стародавньому Римі. URL: http://jak.koshachek.com/articles/sistema-imen-v-starodavnomu-rimi.html (дата звернення: 01.07.2021)

3. Ярцева В. Н. Лингвистический энциклопедический словарь. Москва: «Советская энциклопедия». 1990. URL: http:/tapemark.narod.ru/ les/index.html\#14_(дата звернення: 02.07.2021)

4. Woher kommt der Name «falscher Hase». Pagewitzz. 29.08.2014. URL: https://pagewizz.com/woher-kommt-der-name-falscher-hase-31530/ (дата звернення: 23.04.2021)

5. Wörterbuch für Redensarten, Redewendungen, idiomatische Ausdrücke, Sprichwörter, Umgangssprache. URL: https://www.redensartenindex.de/_(дата звернення: 27.05.2021)

DOI https://doi.org/10.30525/978-9934-26-110-7-38

\section{НОВОЗЕЛАНДСЬКА ПОЕЗІЯ У СУЧАСНИХ ФІЛОЛОГІЧНИХ ДОСЛІДЖЕННЯХ}

\author{
Погорлецька Н. В. \\ аспірантка кафедри англійської мови та методики ї̈ викладання \\ Херсонський держаний університет \\ м. Херсон, Украӥна
}

Століттями питання взаємозв'язку мови та культури не дає спокою мислителям, філософам та науковцям. Прагло вбираючи звичаї, вірування, міфи, перекази, мова назавжди закарбовує у своїй пам'яті культурну спадщину народу. Сьогодні серед германістів глибоку зацікавленість викликає колоритна англомовна література, як-от: африканськоамериканська (Воробей Н.В., Фролова Н.С.), амеріндіанська (Волкова 